\title{
Effect of Fly Ash and Nitrogen on the Growth and Productivity of Oat
}

\author{
Ramandeep Singh, Balwinder Singh Dhillon* and Gurjant Singh Sidhu \\ Department of Agronomy, College of Agriculture, Guru Kashi University, \\ Talwandi Sabo, Bathinda (Punjab), India \\ *Corresponding author
}

\section{A B S T R A C T}

\begin{tabular}{|l|}
\hline K e y w o r d s \\
$\begin{array}{l}\text { Fly ash, Growth, } \\
\text { Nitrogen, Oat and } \\
\text { Yield }\end{array}$ \\
\hline Article Info \\
\hline $\begin{array}{l}\text { Accepted: } \\
\text { 18 July 2020 } \\
\text { Available Online: } \\
\text { 10 August } 2020\end{array}$ \\
\hline \hline
\end{tabular}

\section{Introduction}

Oats (Avena sativa L.) are a diploid species with chromosome number $(2 \mathrm{n}=2 \mathrm{x}=14)$ belongs to the family of Poaceae or Gramineae. Cereals for human nutrition are on the first place in the world and in our country. The oat plant in cereals for animal feed is also healthy and useful addition to the human diet (Peterson et al., 1998). In recent years, because of health benefit claims of oat diet, its importance is gradually increased and gave rise to breakfast, snacks, biscuits and baby foods industries (Guler, 2011). Oat has been cultured for about 2000 years, and is used as animal feed and human food.
The use of mineral fertilizers is the quickest and surest way of boosting crop production. However, their cost and other constraints frequently deter farmers from using them in recommended quantities and in balanced proportions. Complementary use of plant nutrients from waste materials along with mineral fertilizers is of great importance in the maintenance of farm productivity and profitability. Fly ash, a major industrial waste and byproduct produced from thermal power stations, is a low density ferro-alumino silicate. Presence of various elements such as $\mathrm{P}, \mathrm{K}, \mathrm{Ca}, \mathrm{Mg}, \mathrm{S}$ and micronutrients in the fly ash make it a good source of plant nutrients (Deshmukh et al., 2000). The increase yield of different crops due to application of fly ash 
was observed by Kuchanwar and Matte (1997). Oat needs not only macronutrients but secondary as well as micronutrients to produce higher yields. Use of manures, organic and inorganic wastes and biofertilizers is gaining wider acceptance to reduce input cost and to sustain soil fertility. Therefore, this research work was aimed to determine the response of oat to different doses of fly ash and nitrogen on growth and productivity.

\section{Materials and Methods}

The present investigation "Effect of fly ash and nitrogen on the growth and productivity of oat (Avena sativa L.)" was conducted at experimental farm of University College of Agriculture, Guru Kashi University Talwandi Sabo, Bathinda during rabi season 20182019. Soil of experimental field was sandy loam in texture. The soil was alkaline $(\mathrm{pH}$ 7.4) and with normal electrical conductivity $\left(0.34 \mathrm{dSm}^{-1}\right)$. The soil was low in organic carbon content $(0.34 \%)$. The available nitrogen $(225.0 \mathrm{~kg} / \mathrm{ha})$ was low, whereas the available phosphorus (13.9 $\mathrm{kg} / \mathrm{ha})$ and available potash $(245.6 \mathrm{~kg} / \mathrm{ha})$ were medium. The experiment was laid out in split plot design with three replications. The treatments comprised of Three levels of fly ash $(0,5,10 \mathrm{t}$ $\left.\mathrm{ha}^{-1}\right)$ and four level of nitrogen $(0,37.5,75$ and $112.5 \mathrm{~kg} \mathrm{ha}^{-1}$ ). Source of fly ash was thermal power plant at village Banawala, Mansa Talwandi sabo road, District Mansa, Punjab, India.

The height of five randomly selected plants was measured at maturity. The number of grains per panicle counted from the ears of the tagged plants. Dry matter accumulation was recorded from each plot and then converted into $\mathrm{q} \mathrm{ha}{ }^{-1}$. The plant biomass harvested from individual plots was first sun dried followed by oven drying at $65^{\circ} \mathrm{C}$ till constant weight was obtained. After complete drying, dry weight was recorded and converted into $\mathrm{q} / \mathrm{ha}$ Leaf area index (LAI) was recorded at spikelet formation first measure the leaf length, width of leaf and then count the leaf of each tiller and then count the number of tillers per plant.

LAI $=\frac{\text { Leaf } \text { area }}{\text { Ground area }}$.

The total biomass was recorded after complete drying of the harvested crop from each plot. The weight of total produce/plot was recorded after harvest of the crop with help of spring balance. Then the weight of grain per net plot was recorded after threshing of the harvested produce from each bundle and mean converted into the grain yield $\mathrm{kg} \mathrm{ha}^{-}$ 1 . Number of effective tillers per meter row length were taken differently from every two sites from each plot. The weight of randomly 1000-grains was recorded from each plot and expressed in gram (gm). Harvest index (HI) was calculated by using following formula;

Harvest Index $(\%)=\frac{\text { Grain yield }}{\text { Biological yield }} \times 100$

\section{Results and Discussion}

\section{Growth parameters}

The maximum plant height $(170.6 \mathrm{~cm})$ was recorded in application of $10 \mathrm{t}$ fly ash $\mathrm{ha}^{-1}$ which was at par with plant height $(169.2 \mathrm{~cm})$ recorded at the application of $5 \mathrm{t}$ fly ash $\mathrm{ha}^{-1}$ (Table 1). While minimum plant height (166.8 $\mathrm{cm})$ was recorded at control. Similarly, the application of nitrogen increases the plant height and maximum plant height $(176.1 \mathrm{~cm})$ was observed at $112.5 \mathrm{~kg} \mathrm{~N} \mathrm{ha}^{-1}$ application which was at par with plant height $(174.1 \mathrm{~cm})$ recorded at the application of $75 \mathrm{~kg} \mathrm{~N} \mathrm{ha}^{-1}$. While, lowest plant height $(160.2 \mathrm{~cm})$ was recorded under control. The interaction effect 
between fly ash and nitrogen was non significant.

Significantly highest leaf area index (3.17) was observed with application of fly ash $10 \mathrm{t}$ $\mathrm{ha}^{-1}$ as compare to other fly ash treatment (Table 1). While, lowest leaf area index (2.83) was observed at control. Increased nitrogen levels resulted in increase leaf area index. The highest leaf area index (3.28) was recorded with application of $112.5 \mathrm{~kg} \mathrm{~N} \mathrm{ha}^{-1}$ which was at par with leaf area index (3.17) was recorded at the application of $75 \mathrm{~kg} \mathrm{~N} \mathrm{ha}^{-1}$, While, lowest leaf area index (2.68) was recorded at control. The interaction effect between fly ash and nitrogen was non significant.

Application of $10 \mathrm{t}$ fly ash $\mathrm{ha}^{-1}$ recorded maximum dry matter accumulation (139.4 q $\mathrm{ha}^{-1}$ ) which was at par with $5 \mathrm{t}$ fly ash $\mathrm{ha}^{-1}$ treatment (Table 1). The minimum dry matter accumulation (133.2 $\mathrm{q} \mathrm{ha}^{-1}$ ) was recorded in control. Dry matter accumulation was increased with increase nitrogen levels. The highest dry matter accumulation (157.1 q ha-1) was recorded with application of $112.5 \mathrm{~kg} \mathrm{~N}$ $\mathrm{ha}^{-1}$ which was at par with $\left(155.1 \mathrm{q} \mathrm{ha}^{-1}\right)$ dry matter accumulation recorded at $75 \mathrm{~kg} \mathrm{~N} \mathrm{ha}^{-1}$ application. And lowest dry matter accumulation (106.3 q ha ${ }^{-1}$ ) was recorded under control. The interaction effect between fly ash and nitrogen was non significant.

The variation in the above mentioned growth parameters have also been reported by many research workers Deshmukh et al., (2000), Brown et al., (1961); Brinkman and Rho (1984), Akbari et al., (1988), Summers et al., (1998), Malik et al., (2015).

\section{Yield attributes}

The maximum number of effective tillers per meter row length of oat (108.8) was recorded at the application of $10 \mathrm{t}$ fly ash $\mathrm{ha}^{-1}$ was at par with (106.4) number of effective tillers recorded at the application of $5 \mathrm{t}$ fly ash $\mathrm{ha}^{-1}$ (Table 2). The minimum effective tillers (103.3) were recorded in control. Experimental data indicated that increase in levels of nitrogen increase of number of effective tillers The maximum number of effective tillers (112.6) recorded at the application of $112.5 \mathrm{~kg} \mathrm{~N} \mathrm{ha}^{-1}$ which was at par with (109.4) effective tillers recorded at the application of $75 \mathrm{~kg} \mathrm{~N} \mathrm{ha}{ }^{-1}$, while minimum number of effective tillers (98.5) was recorded under control.

The maximum number of grains per spikelet (99.3) was recorded with the application of 10 $\mathrm{t} \mathrm{ha}^{-1}$ was at par with number of grains per spikelet (97.3) was recorded at the application of $5 \mathrm{t}$ fly ash ha ${ }^{-1}$ (Table 2). While minimum number of grains (92.3) per spikelet was recorded in control. Increase in nitrogen levels increased number of grains per spikelet. The maximum number of grains per spikelet (108.0) was recorded at the application of $112.5 \mathrm{~kg} \mathrm{~N} \mathrm{ha}^{-1}$ which was at par with number of grains per spikelet (104.9) was recorded with the application of $75 \mathrm{~kg} \mathrm{~N} \mathrm{ha}^{-1}$. While, minimum number of grains per spikelet (77.8) was recorded under control. The significant interaction effect of fly ash $10 \mathrm{t} \mathrm{ha}^{-1}$ and 112.5 $\mathrm{kg} \mathrm{N} \mathrm{ha}^{-1}$ resulted maximum number of grains (112.2) per spikelet.

The significantly maximum test weight (31.2 g) was recorded in application of $10 \mathrm{t}$ fly ash $\mathrm{ha}^{-1}$ as compare to other fly ash treatments and minimum test weight (27.6 g) was recorded at control (Table 2). Data indicated that increase in nitrogen levels increased test grain weight. Maximum test weight $(31.0 \mathrm{~g})$ was recorded at the application of $112.5 \mathrm{~kg} \mathrm{~N}$ $\mathrm{ha}^{-1}$ which was at par with (30.5 g) test weight was recorded at the application of $75 \mathrm{~kg} \mathrm{~N}^{-}$ 1 . Minimum test weight (27.3 g) was recorded under control. The interaction effect between fly ash and nitrogen was non significant. The 
variation in the above mentioned growth parameters have also been reported by many research workers Khan et al., (1997), Jat et al., (2017) and Ghosh (1985).

\section{Productivity}

Maximum grain yield $\left(24.2 \mathrm{q} \mathrm{ha}^{-1}\right)$ was recorded at application of $10 \mathrm{t}$ fly ash $\mathrm{ha}^{-1}$ which was at par with grain yield (23.4 $\left.\mathrm{q} \mathrm{ha}^{-1}\right)$ recorded at the application of $5 \mathrm{t}$ fly ash $\mathrm{ha}^{-1}$ (Table 3). Minimum grain yield (20.5 q ha ${ }^{-1}$ ) was obtained at control. The percent increase grains yield at $10 \mathrm{t}$ fly ash ha ${ }^{-1}$ was 3.41 and 18.0 over $5 \mathrm{t}$ fly ash $\mathrm{ha}^{-1}$ application and control, respectively.

Increase the level of nitrogen increase grain yield. The maximum grain yield $\left(25.0 \mathrm{q} \mathrm{ha}^{-1}\right)$ was recorded at application of $112.5 \mathrm{~kg} \mathrm{~N} \mathrm{ha}^{-1}$ which was at par with grain yield $\left(23.9 \mathrm{q} \mathrm{ha}^{-1}\right)$ was recorded at application of $75 \mathrm{~kg} \mathrm{~N} \mathrm{ha}^{-1}$, while minimum grain yield $\left(19.4 \mathrm{q} \mathrm{ha}^{-1}\right)$ was recorded at control.

Table.1 Effect of fly ash and nitrogen on growth parameters of oat

\begin{tabular}{|c|c|c|c|}
\hline Treatments & $\begin{array}{c}\text { Plant height } \\
(\mathbf{c m})\end{array}$ & Leaf area index & $\begin{array}{c}\text { Dry matter } \\
\text { accumulation }\left(\mathbf{q} \mathbf{~ h a}^{-\mathbf{1}}\right)\end{array}$ \\
\hline Fly ash levels $\left(\mathbf{t ~ h a}^{\mathbf{- 1}}\right)$ & & & \\
\hline $\mathbf{0}$ & 166.8 & 2.83 & 133.2 \\
\hline $\mathbf{5}$ & 169.2 & 3.02 & 138.1 \\
\hline $\mathbf{1 0}$ & 170.6 & 3.17 & 139.4 \\
\hline CD at 5\% & 1.6 & 0.10 & \\
\hline Nitrogen levels $\left(\mathbf{k g ~ h a}^{-\mathbf{1}}\right)$ & & & 106.3 \\
\hline $\mathbf{0}$ & 160.2 & 2.68 & 129.2 \\
\hline $\mathbf{3 7 . 5}$ & 164.4 & 2.92 & 155.1 \\
\hline $\mathbf{7 5}$ & 174.1 & 3.17 & 157.1 \\
\hline $\mathbf{1 1 2 . 2}$ & 176.1 & 3.28 & 2.4 \\
\hline CD at 5\% & 2.1 & 0.12 & \\
\hline
\end{tabular}

Table.2 Effect of fly ash and nitrogen levels on yield attributing characters of oat

\begin{tabular}{|c|c|c|c|}
\hline Treatment & $\begin{array}{c}\text { Number of tillers / } \\
\text { meter row length }\end{array}$ & $\begin{array}{c}\text { No. of grains per } \\
\text { spikelet }\end{array}$ & Test weight (g) \\
\hline Fly ash levels $\left(\mathbf{t ~ h a}^{-\mathbf{1}}\right)$ & & & \\
\hline $\mathbf{0}$ & 103.3 & 92.3 & 27.6 \\
\hline $\mathbf{5}$ & 106.4 & 97.3 & 30.1 \\
\hline $\mathbf{1 0}$ & 108.8 & 99.3 & 31.2 \\
\hline CD at 5\% & 2.5 & 2.1 & 0.8 \\
\hline Nitrogen levels $\left(\mathbf{k g ~ h a}^{-\mathbf{1}}\right)$ & & & 27.3 \\
\hline $\mathbf{0}$ & 98.5 & 77.8 & 29.7 \\
\hline $\mathbf{3 7 . 5}$ & 104.1 & 94.4 & 30.5 \\
\hline $\mathbf{7 5}$ & 109.4 & 104.9 & 31.0 \\
\hline $\mathbf{1 1 2 . 5}$ & 112.6 & 108.0 & 0.6 \\
\hline CD at 5\% & 3.3 & 3.3 & \\
\hline
\end{tabular}


Table.3 Effect of different fly ash and nitrogen levels on productivity in oat

\begin{tabular}{|c|c|c|c|c|}
\hline Treatment & $\begin{array}{c}\text { Grain yield } \\
\text { (q/ha) }\end{array}$ & $\begin{array}{c}\text { Straw yield } \\
\text { (q/ha) }\end{array}$ & $\begin{array}{c}\text { Biological yield } \\
\text { (q/ha) }\end{array}$ & $\begin{array}{c}\text { Harvest } \\
\text { index }(\%)\end{array}$ \\
\hline \multicolumn{5}{|c|}{ Fly ash levels t ha ${ }^{-1}$} \\
\hline 0 & 20.5 & 129.5 & 150.0 & 13.6 \\
\hline 5 & 23.4 & 136.7 & 160.1 & 14.6 \\
\hline 10 & 24.2 & 139.5 & 163.8 & 14.8 \\
\hline CD at $5 \%$ & 1.0 & 3.8 & 3.9 & NS \\
\hline \multicolumn{5}{|c|}{ Nitrogen levels $\left(\mathrm{kg} \mathrm{ha}^{-1}\right)$} \\
\hline 0 & 19.4 & 101.7 & 121.2 & 16.0 \\
\hline 37.5 & 22.4 & 138.8 & 156.2 & 14.3 \\
\hline 75 & 23.9 & 151.8 & 175.7 & 13.6 \\
\hline 112.5 & 25.0 & 153.8 & 178.8 & 13.9 \\
\hline CD at $5 \%$ & 1.2 & 3.9 & 4.1 & NS \\
\hline
\end{tabular}

The percent increase in grain yield with 112.5 $\mathrm{kg} \mathrm{N} \mathrm{ha}^{-1}$ was $4.60,11.60$ and 28.8 over $75 \mathrm{~kg}$ $\mathrm{N} \mathrm{ha}{ }^{-1}$, $37.5 \mathrm{~kg} \mathrm{~N} \mathrm{ha}{ }^{-1}$ and control, respectively. The interaction effect between different fly ash and nitrogen levels showed that significant grain yield of oat. The application of $10 \mathrm{t}$ fly ash ha ${ }^{-1}$ with $112.5 \mathrm{~kg}$ $\mathrm{N} \mathrm{ha}^{-1}$ produced maximum grain yield $(26.9 \mathrm{q}$ $\left.\mathrm{ha}^{-1}\right)$. Minimum grain yield $\left(16.8 \mathrm{q} \mathrm{ha}^{-1}\right)$ recorded in control.

The maximum straw yield (139.5 $\left.\mathrm{q} \mathrm{ha}^{-1}\right)$ was recorded at the application of $10 \mathrm{t}$ fly ash $\mathrm{ha}^{-1}$ which was at par with $\left(136.7 \mathrm{q} \mathrm{ha}^{-1}\right)$ application of $5 \mathrm{t}$ fly ash ha ${ }^{-1}$ (Table 3). While the minimum straw yield $\left(129.5 \mathrm{q} \mathrm{ha}^{-1}\right)$ was recorded at control. Increase in straw yield with each increment of nitrogen application. The highest straw yield (153.8 q ha $\left.{ }^{-1}\right)$ was recorded at $112.5 \mathrm{~kg} \mathrm{~N}^{-1}$ application which was at par with $\left(151.8 \mathrm{q} \mathrm{ha}^{-1}\right)$ straw yield was recorded at the application of 75 $\mathrm{kg} \mathrm{N} \mathrm{ha}^{-1}$. While lowest straw yield $(101.7 \mathrm{q}$ $\mathrm{ha}^{-1}$ ) was recorded at control. The interaction effect between fly ash and nitrogen was non significant.

The highest biological yield $\left(163.8 \mathrm{q} \mathrm{ha}^{-1}\right)$ was recorded at $10 \mathrm{t}$ fly ash $\mathrm{ha}^{-1}$ application which was at par with biological yield (160.1 $\mathrm{q} \mathrm{ha}^{-1}$ ) application of $5 \mathrm{t}$ fly ash $\mathrm{ha}^{-1}$ (Table 3 ). Whereas, the minimum biological yield $\left(150.1 \mathrm{q} \mathrm{ha} \mathrm{ha}^{-1}\right)$ was recorded under control. Increase nitrogen level with each increment increase biological yield. Maximum biological yield $\left(178.8 \mathrm{q} \mathrm{ha}^{-1}\right)$ was obtained with the application of $112.5 \mathrm{~kg} \mathrm{~N} \mathrm{ha}{ }^{-1}$ application which was at par with (175.7 $\mathrm{q} \mathrm{ha}^{-1}$ ) biological yield was recorded at the application of $75 \mathrm{~kg} \mathrm{~N} \mathrm{ha}^{-1}$. While the minimum biological yield (121.2 $\left.\mathrm{q} \mathrm{ha}^{-1}\right)$ was recorded at control. The interaction effect between fly ash and nitrogen was non significant.

The data indicated that harvest index increased with increased doses of fly ash. The maximum harvest index (14.8\%) was recorded at application of $10 \mathrm{t}$ fly ash $\mathrm{ha}^{-1}$ (Table 3). While minimum harvest index (13.6\%) was recorded at control. The data also indicated that application of nitrogen showed, increase in harvest index measured up to control. The maximum harvest index $(16.0 \%)$ was recorded at control. While minimum harvest index (13.6\%) was reported at $75 \mathrm{~kg} \mathrm{~N} \mathrm{ha}{ }^{-1}$. The interaction effect between fly ash and nitrogen was non significant. The variation in the above mentioned growth parameters have also been 
reported by many research workers Prasad et al., (2000), Tiwana et al., (2004) and Chalmers et al., (1998).

So on the basis of above finding it can be concluded the application of fly ash@10 t $\mathrm{ha}^{-1}$ in oat crop improved the growth and yield of oat. Application of $112.5 \mathrm{~kg} \mathrm{~N} \mathrm{ha}^{-1}$ increased growth and yield attributes resulted in maximum grain yield of oat as compared to other levels of nitrogen. Fly ash @ $10 \mathrm{t} \mathrm{ha}^{-1}$ and $112.5 \mathrm{~kg} \mathrm{~N} \mathrm{ha}^{-1}$ on gave significantly maximum grain yield. Application of fly ash is not a proper substitute of nitrogen application on oat crop. Thus use of fly ash will help to increase the crop yield as well as reduce the burden to dispose-off the fly ash.

\section{References}

Akbari, K.N., Sutaria, G.S., Hirpara, D.S. and Yusufzai, A.S. 1998. Response of groundnut to $\mathrm{P}$ fertilization with different tillage practices under rainfed agriculture. Indian J. Agic. Res. 32: 171-117

Brinkman, M.A. and Rho, Y.D. 1984. Response of three oat cultivars to $\mathrm{N}$ fertilizer. Crop Sci. 24: 973-977.

Brown, A.R., Morris, H.D. and Morey, D.D. 1961. Response of seven oat varieties to different levels of fertilization. Agronomy J. 53: 366-369.

Chamers A.G., Dyer C.J., Sylvester, and Bradely, R. 1998. Effect of nitrogen fertilizer on grain yield and quality of winter oats. Indian J. Agric. Sci. 137(4): 395-407.

Deshmukh., Anjali., Matte, D.B. and
Bhaisare, B. 2000. Soil properties as influenced by flyash application. $J$. Soils Crops 10: 69-71.

Ghosh, D.C. 1985. Influence of nitrogen, phosphorus and cutting on growth and yield of oats. Indian J. Agron. 30: 172176.

Guler, M. 2011. Nitrogen and irrigation effect on grain ü-glucan content of oats (Avena sativa L.). AJCS 5: 242-247.

Jat, H., Kaushik, M.K., Nepalia, V. and Singh, D. 2017. Effect of irrigation schedule and nitrogen fertilization on growth, yield and quality of fodder oat (Avena sativa L.) J. Pharmacognosy Phytochem. 6: 2040-2042

Khan, S., Begum, T. and Singh, J.N. 1996. Effect of fly ash on physiochemical properties and nutrient status of soil. Indian J. Environ. 38: 41- 46.

Kuchanwar, O.D. and Matte, D.B. 1997. Evaluation of graded doses of fly ash and fertilizers on nutrient content and uptake of groundnut grown on vertisol. J. Soils Crops, 7: 1-3.

Malik, P., Duhan, B.S. and Midha, L.K. 2015. Effect of fertilizer application and cutting schedule on growth and yield parameters in oat (Avena sativa L.). Forage Res. 40:264-267.

Patel, J. R. and Rajgopal, S. 2002. Response of forage oat (Avena sativa L.) to levels of nitrogen and phosphorus. Indian J. Agron. 47: 134-137.

Tiwana, U.S. and Puri K.P. 2004. Effect of Azotobactor and nitrogen levels on the seed yield of oats (Avena sativa L.). Forage Res. 29(4): 210-211.

\section{How to cite this article:}

Ramandeep Singh, Balwinder Singh dhillon and Gurjant Singh Sidhu. 2020. Effect of Fly Ash and Nitrogen on the Growth and Productivity of Oat. Int.J.Curr.Microbiol.App.Sci. 9(08): 1732-1737. doi: https://doi.org/10.20546/ijcmas.2020.908.199 